\title{
Instructional Leadership and Teachers' Functional Competency across the 21st Century Learning
}

\section{Siti Noor Ismail}

Dr., School of Education, Universiti Utara Malaysia, Malaysia, siti.noor@uum.edu.my

\author{
Yahya Don \\ Prof., AP., School of Education, Universiti Utara Malaysia, Malaysia, \\ d.yahya@uum.edu.my
}

\section{Fauzi Husin}

AP., School of Education, Universiti Utara Malaysia, Malaysia, fauzi@uum.edu.my

\section{Rozalina Khalid}

School of Education, Universiti Utara Malaysia, Malaysia, rozalina@uum.edu.my

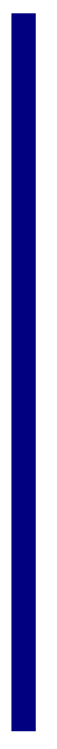
This study examined the relationship between school leaders' instructional leadership and teachers' functional competency in high prestige schools in the Northern part of Peninsular Malaysia. The research design employed for this study was descriptive method of the correlational survey type. This survey was administered to 225 teachers from 12 secondary and primary schools to collect the necessary data. Principal Instructional Management Rating Scale Questionnaire was adopted from Hallinger and Murphy (1985) and Integrated Assessment Module for Education Services Officers (2014) was used to obtain the data. The study found that the level of instructional leadership among the leaders as high $(\mathrm{M}=3.94, \mathrm{SD}=.55)$ and the level of teachers' functional competency as very high $(\mathrm{M}=4.23, \mathrm{SD}=.41)$. The finding also revealed that there is a very strong significant relationship between school leaders' instructional leadership and teachers' functional competency $(\mathrm{r}=.956, \mathrm{p}=.000)$. The findings further suggested that there is an averagely strong significant relationship $(r=.397, p=.000)$ between school leaders' instructional leadership and teachers' knowledge; and a positive with weak but significant relationship $(r=.345, \mathrm{p}=.000)$ between school leaders' instructional leadership and teachers' skills. This study recommends that school leaders adopt instructional leadership in their practices to improve teachers' functional competency.

Keywords: teachers' functional competency, instructional leadership, quality management, $21^{\text {st }}$ century learning, schools of high prestige

Citation: Ismail, S. N., Don, Y., Husin, F., \& Khalid R. (2018). Instructional Leadership and Teachers' Functional Competency across the 21st Century Learning. International Journal of Instruction, 11(3), 135-152. https://doi.org/10.12973/iji.2018.11310a 


\section{INTRODUCTION}

Learning and innovation skills are increasingly being recognized as domains that separate students who are prepared for a more complex life and work environments in the 21 st century from those who are not. A focus on creativity, critical thinking, communication and collaboration is essential to prepare students for the future. In part of this, much research has shown that the educational experience for students is significantly dependent on the quality and effectiveness of teachers, more than any other single alterable factor (Darling-Hammond, 1999; Rowan, 2004). This has led to the efforts to identify teaching core competencies based on effective teaching attributes in terms of subject matter knowledge, pedagogical content knowledge, knowledge of teaching and learning, curricular knowledge, teaching experience, certification status, and so on (Grossman, 1995; Rice, 2003; Wayne \& Youngs, 2003).

School leaders play very significant role towards the success of their schools. They carry countless responsibilities (Shen \& Cooley, 2010) to manage the school administration matters such as budget and timetables, students' discipline and attendance, cocurriculum activities, facilities, safety, recruitment and monitoring of teachers, assessments, curriculum, teaching and learning materials professional development (Murphy, Elliott, Goldring \& Porter, 2007), relationships with teachers and students (Quinn, 2002), and communication with parents and the surrounding community (Horng, Klasik, \& Loeb, 2010; Goldring, Huff, May, \& Camburn, 2008; Spillane, Camburn, \& Pareja, 2007).

Recent studies have showed that school principals have small to average influence towards students' academic achievement (Hendriks \& Steen, 2012; Huber \& Muijs, 2010; Leithwood, Harris, \& Hopkins, 2008; Robinson, Lloyd, \& Rowe, 2008; Witziers, Bosker, \& Kruger, 2003). However, their influence showed an increase in classroom instructions (Robinson, Lloyd, \& Rowe, 2008) and in teachers' behaviour, beliefs, knowledge, practice and competency (Hendriks \& Steen, 2012; Leithwood, Harris, \& Hopkins, 2008).

The rational for this assumption is that (1) teachers' efficacy belief has significant positive relationship with students' academic achievements (Moolenaar, Sleegers, \& Daly, 2012; Fancera \& Bliss 2011; Guo, Piasta, Justice, \& Kaderavek, 2010; Caprara, Barbaranelli, Steca, \& Malone, 2006); (2) instructional leadership acts as the source to teachers' efficacy belief according to Bandura's Social Cognitive Theory (Ross, Hogaboam-Gray, \& Gray, 2004; Ebmeier, 2003), and (3) one of the reasons for instructional leadership practice is to increase classroom instructions by giving positive influence towards teachers' behaviour, belief (including teachers' efficacy and collective teachers' efficacy), knowledge, practice, and teachers' competency (Blase \& Blase, $2000 ; 1999)$. Therefore, by using instructional leadership practice, school principals are able to positively increase their teachers' efficacy belief and, indirectly, increase their classroom instructions; and their students' academic achievements.

The research related to instructional leadership and teacher competencies is emerging. Rosnarizah (2015); Buczynski \& Hansen (2010); Hallinger (2005); and Darling- 
Hammond (1999) have reported that leadership styles have a significant correlation with teachers' efficacy and competencies. In addition, research has demonstrated that teaching leadership behaviour factors such as giving feedback, praising, encouraging and supporting various learning and teaching approaches, emphasizing learning and teaching exercises, supporting collaborative efforts, and starting teamwork is a predictor of school climate (Gu Saw Lan, 2014). While other efforts such as giving feedback, suggesting, encouraging and supporting various methods of learning and teaching, decision-making based on action research data, and supporting collaborative efforts are the predictors of self-efficacy and teachers' competency.

Several past studies showed that school leaders (including instructional leadership practice) influence teachers' efficacy (Hoy \& Tarter, 2011). However, there are only a few studies conducted to examine the relationship between school leaders' instructional leadership and teachers' functional competency. The issue of how school leaders practice instructional leadership to increase teachers' efficacy beliefs and teachers' competency; and to improve teachers' classroom instructions needs to be addressed. Thus, this study was conducted to identify the level of instructional leadership among school leaders, the level of teachers' functional competency; and the relationship between these two variables with its dimensions.

\section{THEORETICAL BACKGROUND}

\section{Instructional Leadership}

Instructional Leadership is an approach used by school leaders to focus on teachers' behaviour in certain activities which indirectly impacts students' academic achievement (Leithwood, Jantzi \& Steinbach, 2000). According to Drake and Roe (2005), the school administrator's main task is to apply instructional leadership because this leadership style is related to the implementation of promoting and improving student learning innovation program. In addition, according to Boe Lahui Ako (2008), instructional leadership is very closely related to the role and duty of a school principal such as developing and disseminating school aims, setting targeted standards, coordinating curriculum, supervising and evaluating teachers' classroom instructions, encouraging students to study and increasing teachers' and administration staff professional development.

Instructional Leadership Theory used in this study is based on the theory by Hallinger and Murphy (1985). According to this theory, there are three (3) dimensions in the instructional leadership framework that are defining the school mission, managing curriculum and instructions, and promoting school learning climate. The three dimensions are showed in Table 1. Each dimension has several specialized task functions which involve principals' behaviour diversity and practices. In the effort to define school mission, leaders plan school aims with the staff and parents to determine the areas to be improved in school besides setting the aims for each area. Disseminating school aims is the ways leaders share the importance of the school's aims with the staff, parents and students. This can be achieved through formal and informal communication. 
The dimension managing instructional programs, involves effort with teachers in curriculum and instructions. Among the tasks are supervising and evaluating classroom instructions which consist of supported learning materials, monitoring classroom instructions through informal visits to the class and coordinating classroom practices in line with the school's aims stipulated in the first dimension. The task of coordinating curriculum refers to activities that enable the staff to cooperate and formalize teaching standard already set and achievement test already prepared.

Table 1

Instructional Leadership Framework

\begin{tabular}{ll}
\hline \multicolumn{1}{c}{ Dimension } & \multicolumn{1}{c}{ Function } \\
\hline $\begin{array}{l}\text { Defining the school } \\
\text { mission }\end{array}$ & $\begin{array}{l}\text { 1. Drafting school aims } \\
\text { 2. Disseminating school aims }\end{array}$ \\
\hline \multirow{2}{*}{$\begin{array}{l}\text { Managing curriculum and } \\
\text { instructions }\end{array}$} & $\begin{array}{l}\text { 3. Supervising and Evaluating Teachers' Classroom Instructions } \\
\text { 4. Coordinating Curriculum } \\
\text { 5. Monitoring Students' progress }\end{array}$ \\
Promoting school & 6. Protecting Teaching and Learning Time \\
learning climate & 7. Enriching Professional Development \\
& 9. Maintaining High Visibility \\
& 9. Provides incentives for teachers \\
\hline
\end{tabular}

(Source: Hallinger \& Murphy, 1985)

Provides incentives for learning refers to usage of post-mortem data from students' tests to set suitable aims, evaluating the effectiveness of classroom instructions and identify the level of progress to suit the stipulated target. Moving on to the next dimension which is developing positive school climate, school leaders indirectly, inculcate optimum learning environment. According to Hallinger \& Murphy (1985), leaders are able to influence students' and teachers' behaviour by creating a reward system which will consolidate their achievements and productive efforts. This can be done by explaining to the students clearly, the school's expectation of them, accuracy of using school time and for the teachers; undergo selection and implementation of teacher's professional development program.

\section{Teachers' Functional Competency}

Competency involves generic skills, basic skills, main skills and personal skills which refer to knowledge and skills as well as the attitude of an individual. In other words, competency is the combination of knowledge, effort and experience which enable an individual to complete a task perfectly (Nijveldt, Beijaard, Brekelmans, Verloop \& Wubbels, 2005). According to Main and Hammond (2008), competency is defined as the combination of knowledge, skills and personal characteristics which should be owned and practiced in order to complete a certain task or position. Competencies reinforce one another from basic to advanced as learning progresses; the impact of increasing competencies is synergistic, and the whole is greater than the sum of the parts 
(Council on Education for Public Health, 2006). Teacher's competency comprises of personal, professional and social aspects such as teaching, as an expert in the subject related to teaching and learning, as an expert in theories related to teaching and learning, managing learning processes and adapting oneself in the community (Klassen \& Chiu, 2010).

Meanwhile, Blanchard and Thacker (2004) define competency as a group of knowledge, skills and attitude which normally is used to differentiate one's performance (Leithwood \& Jantzi, 2006). According to Ball and Mc Diarmid (1990), teacher's role is very vital and critical in explaining the subject matter to the students. They summarized that teachers who are without in-depth knowledge of their subject contents will not be able to challenge students' knowledge and ability. The difference in academic achievement is due to the difference in the teaching and learning processes practiced by the teachers, higher expectations from the students, emphasizing on mastery learning, creating opportunities to learn and manage classroom effectively (Brophy, 1992). All these factors lead to teacher's functional competency which should be possessed by all teachers so as to ensure effective teaching and learning processes and display students' successful output (Malaysian Education Ministry, 2014).

A teacher is considered as being a quality teacher when he/she is able to diversify the learning methodologies, prepare effective audio visual aids, study the contents to be taught, know the students' level of ability in absorbing the knowledge disseminated to them, motivate students, monitor and control students' behaviours, classify students based on groups and provide continuous assessment to the students (Murphy, Elliott, Goldring \& Porter, 2007). Teachers with good teaching competency are teachers who have the ability to deliver teaching, concepts and skills that are easily understood by the students, easily remembered and attract students' interest to the teaching and learning. In fact, lack of quality in terms of science and mathematics subject achievement is due to the issue that teachers, especially Mathematics teachers who are incompetent in teaching and learning practice that needs students to think critically and creatively (NCTM, 2000). Thus, quality of education does refer to quality of classroom instructions (Safia Saeed, 2009) and they are seen based on two main dimensions; namely, teachers' knowledge in the content subject and teachers' skills in administering the teaching and learning processes.

In summary, an efficient teacher has to have the element of functional competency which comprises of mastery in the content subject taught, knowledgeable in pedagogical process, has the ability to select effective learning resources, has the ability to diversify teaching strategies based on students' level of intelligence, has ICT skills (McCoy, 2001), has an effective communication skills, able to create good interpersonal relationship, has positive attitude and personality such as being patient, highly motivated, confident, flexible and has rapport with students (Malaysian Education Ministry, 2014). 


\section{Competency Model and Theory}

The basic principle of competency model is that an individual's performance will increase if one has all the competencies needed to complete the tasks and responsibilities. For instance, an expert in one field and the frequency of one's completing the task will enable one to do one's job effectively and brilliantly (Safia Saeed, 2009; Wayne, \& Youngs, 2003,). For example, an academic teacher should have functional competency which focuses on the knowledge and skills aspects that involve the knowledge to plan teaching and learning, assessment and skills in knowledge delivery, use of relevant sources, communication, producing various questioning techniques, encourages students' participation and also evaluate students' performance (Malaysian Education Ministry, 2014).

According to the competency model developed by Hay Mc Ber (2003), skills and knowledge are usually obtained through courses and trainings and can also be related to academic qualification. The development of an individual's personal characteristics is very challenging and has to be given special emphasis so as to achieve targeted success through trainings and continuous development program. For this model, competency is symbolised as an iceberg whereby skills and knowledge are at the tip of an iceberg and are submerged in water. Whereas, trait or personality is positioned under water and is unpredictable. Nevertheless, skills and knowledge although needed to complete a task, they do not differ in terms of performance. The behaviour element set by hidden personal characteristics is an important factor which can help differentiate staff of high performance from staff of average performance (Diagram 1).

Based on Diagram 1, the Iceberg Competency Model consists of seven (7) categories of competency which is divided into two competency groups namely (i) Knowledge/Skill Competency Group showed as part of the iceberg being as above the water level. This group of competency comprises two (2) elements that are Knowledge and Skill; and (ii) Behavioural Competency Group which is shown as the part of iceberg being under the water level. This behavioural competency group comprises of five (5) competency components that are (i) values (ii) social role (iii) self-image (iv) traits (personality) (v) Motive. Although basically, competency is divided into two (2) groups but recent researches have shown that behavioural competency is the real factor that differentiate an average worker from a successful worker in completing a task. 


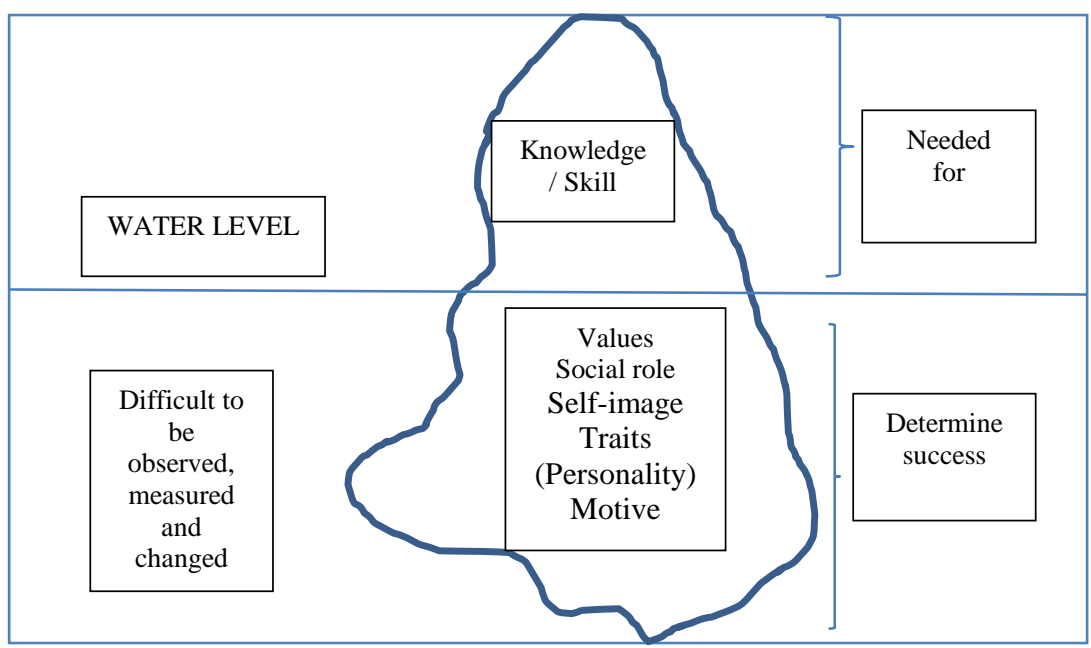

Diagram 1: Iceberg Competency Model (Source: Hay Group Malaysia, 2003)

Aptitude test and knowledge that is frequently used do not determine an individual's work performance and many at times bias happens on the minority group, women and the disabled (McClelland, 1973). Nevertheless, various organizations at present still practice and put importance on knowledge and skills because they are easier to be evaluated and exhibited through certificates and service records (Malaysia Public Service Department, 2004). The knowledge and skill elements are categorized as competency component which is easily evaluated and identified whereas traits or personality is the supporting component which is difficult to be seen but contribute to the increase of knowledge and skills. In this study, the researchers focus on only two dimensions of the teachers' functional competency that are knowledge and skill as frequently used by Ornstein (1991); Anderson (1991); and Whitehurst (2002).

\section{Research Questions}

The following research questions were raised to guide the conduct of the study:

1. What is the level of instructional leadership among school leaders' in high prestige schools in the Northern part of Peninsular Malaysia?

2. What is the level of teachers' functional competency in high prestige schools in the Northern part of Peninsular Malaysia?

3. Is there any significant relationship between school leaders' instructional leadership and teachers' functional competency in high prestige schools in the Northern part of Peninsular Malaysia?

\section{METHOD}

\section{Research Design}

The research design adopted for this study was descriptive survey of the correlational method. Correlational design is appropriate for measuring such complexities of the pattern of relationships that exists among measured variables (Stangor, 2004). 
Descriptive statistics was used to examine the level of school leaders' instructional leadership and teachers' functional competency. Furthermore, inferential statistics (correlation coefficient) was used to examine the relationship between the variables. According to Patton (2002), data obtained from quantitative methodology is systematic, uniform and easy to be presented. The quantitative approach emphasizes on measurement and correlation or relationship between variables. This approach also refers to the use of measurement objectively to produce numerical data which is normally analysed statistically from the responses in the questionnaire (Sekaran, 2003).

\section{Population and Sampling}

The target population for this study comprised all teachers from high prestige schools in the northern part of Malaysia. High prestige schools are chosen because it is a school with an ethos, character, distinctive identity and unique in all aspects of education and able to be competitive in the world. This cluster sampling technique is used in a situation where the population members are naturally grouped into a unit that can be conveniently used as clusters (Sekaran, 2003). A sample of 225 teachers was selected from twelve (12) high prestige schools (primary and secondary) in the northern part of Malaysia. Teachers from the schools involved were selected at random.

\section{Data Collection Tools}

The questionnaire used in this study consists of three (3) sections; section A is related to demography factor, section B consists of items related to the school leaders' instructional leadership practice and items in section $\mathrm{C}$, are related to the teachers' functional competency. In this study, the first instrument is to measure the school leaders' instructional leadership behaviour known as 'Principal Instructional Management Rating Scale' (PIMRS) developed by Hallinger and Murphy (1985). Even it is too old, PIMRS still was used because the original validation study found that the PIMRS met high standards of reliability (Hallinger, 1985). All ten subscales exceeded .80 using Cronbach's test of internal consistency. Subsequent studies have generally substituted Ebel's (1951) test for calculating inter-rater reliability for Cronbach's formula. This test provides a more accurate test of reliability for ratings aggregated from a set of schools where respondents within schools (e.g., teachers) are rating a feature of the school, i.e., the principal).

The second instrument is developed based on the related recent study instruments and adapted also from Malaysian Integrated Assessment Module for Education Services Officers (PBPPP) which was developed by the Curriculum Development Centre, Ministry of Education (2014). The adaptation is based on the past studies and the requirements in Ministry of Education Malaysia. All the instruments are in compliance with the teacher's functional competence theory and the principles of building items have been tested in terms of legality and consistency. Alpha coefficient value for this dimension is 0.9 (Quek, Khatijah \& Azmi, 1996). 
In short, all the instruments conform to the theory of leadership and teachers' functional competence besides following the principles of building items in terms of validity and consistency, as mentioned above. The internal consistency of these two instruments is estimated by calculating the reliability coefficient, $\alpha$. The scores for these two instruments have a very good reliability coefficient of more than 0.80 (Ary, Jacobs \& Razavieh, 2002).

For each item, the rater assesses the frequency with which the principal enacts a behaviour or practice associated with that particular instructional leadership function. Each item is rated on a Likert-type scale ranging from (1) almost never to (5) almost always. The instrument is scored by calculating the mean for the items that comprise each subscale. This results in a profile that yields data on perceptions of principal performance on each of the 10 instructional leadership functions.

\section{FINDINGS}

\section{Profile of the Respondents}

Table 1 indicates the respondents' profile by gender, age and race. The findings show that the respondents comprised $136(60.44 \%)$ female and $89(39.56 \%)$ male teachers with the age ranged between 19 and over 40 years old. The majority came from over 40 years old age groups. In terms of ethnicity there were 193 (85.78\%) Malay, $19(8.44 \%)$ Chinese, 10(4.44\%) Indian and 3 (1.33\%) others.

Table 1

Respondents by Gender, Age, Ethnic and Field of Teaching $(\mathrm{N}=225)$

\begin{tabular}{llll}
\hline Demographic Information & Categories & $\mathrm{N}$ & $\%$ \\
\hline Gender & Male & 89 & 39.56 \\
Age & Female & 136 & 60.44 \\
& $19-25$ & 38 & 16.90 \\
\multirow{5}{*}{ Race } & $26-40$ & 86 & 38.22 \\
& More than 40 & 101 & 44.90 \\
& Malay & 193 & 85.78 \\
\multirow{5}{*}{ Field of Teaching } & Chinese & 19 & 8.44 \\
& Indian & 10 & 4.44 \\
& Others & 3 & 1.33 \\
& Science \& Mathematics & 71 & 31.60 \\
& Language & 77 & 34.20 \\
& Social Science/Humanities & 58 & 25.80 \\
\hline
\end{tabular}

Research Questions 1 \& 2: $\quad$ What is the level of school leaders' instructional leadership and teachers' functional competency in high prestige schools in the Northern part of Peninsular Malaysia?

In order to answer this research questions, respondents' responses on the Instructional Leadership and Teachers' Functional Competency questionnaire were collated. The data collected from the study were analysed, as shown on Table 2. 
Table 2

Mean and Standard Deviation for School Leaders Instructional Leadership and Teachers' Functional Competency

\begin{tabular}{lccc}
\hline \multicolumn{1}{c}{ Variable } & $\mathrm{N}$ & Mean $(\mathrm{M})$ & Std. Deviation (SD) \\
\hline $\begin{array}{l}\text { Instructional } \\
\text { Leadership }\end{array}$ & 225 & 3.94 & 0.55 \\
$\begin{array}{l}\text { Teachers' } \\
\begin{array}{l}\text { Functional } \\
\text { Competency }\end{array}\end{array}$ & 225 & 4.23 & 0.41 \\
\hline
\end{tabular}

Table 2 indicates that 225 respondents participated in this study. Findings showed that the level of school leaders' instructional leadership is high $(\mathrm{M}=3.94, \mathrm{SD}=0.55)$ and the level of teachers' functional competency is very high $(\mathrm{M}=4.23, \mathrm{SD}=0.41)$.

Research Question 3: Is there any significant relationship between school leaders' instructional leadership and teachers' functional competency in high prestige schools in the Northern part of Peninsular Malaysia?

The analysis using Pearson correlation coefficient found that the correlation between school leaders' instructional leadership and teachers' functional competency level has strong positive relationship and significant $(r=.96, p=.00)$ as stated in Table 3.

Table 3

Correlation between School Leaders' Instructional Leadership and Teachers' Functional Competency $(\mathrm{N}=225)$

\begin{tabular}{lcc}
\hline & $\begin{array}{c}\text { School Leaders' } \\
\text { Instructional Leadership }\end{array}$ & $\begin{array}{c}\text { Teachers' Functional } \\
\text { Competency }\end{array}$ \\
\hline School Leaders' & - & $.96^{* *}$ \\
Instructional Leadership & $.96^{* *}$ & - \\
Teachers' Functional Competency & 225 & 225 \\
$\mathrm{~N}$ & &
\end{tabular}

Subsequently, the Pearson analysis which is used in assessing the strength and direction of relevance between school leaders' instructional leadership with teachers' knowledge dimensions showed averagely strong positive relationship but significant $(r=.40, p=$ $.00)$. Meanwhile, for the relationship between the level of school leaders' instructional leadership and teachers' skills dimension, the finding showed that there is weak positive relationship but significant $(r=.35, p=.00)$ for both elements. Indirectly, the finding also showed that there is very strong positive relationship and significant for correlation between both teachers' functional competency dimension, that is teachers' knowledge and teachers' skills $(\mathrm{r}=.83, p=.00)$. 
Table 4

Correlation between School Leaders' Instructional Leadership and Teachers' Knowledge and Teachers' Skills Dimension $(\mathrm{N}=225)$

\begin{tabular}{llll} 
& $\begin{array}{l}\text { School Leaders' } \\
\text { Instructional } \\
\text { Leadership }\end{array}$ & $\begin{array}{l}\text { Teachers' } \\
\text { Knowledge }\end{array}$ & $\begin{array}{l}\text { Teachers' } \\
\text { Skills }\end{array}$ \\
\hline School Leaders' & - & $.40^{* *}$ & $.35^{* *}$ \\
Instructional Leadership & $.40^{* *}$ & - & $.83^{* *}$ \\
Teachers' Knowledge & $.35^{* *}$ & $.83^{* *}$ & - \\
Teachers' Skills & 225 & 225 & 225 \\
$\mathrm{~N}$ & &
\end{tabular}

**. Correlation is significant at confidence level 0.01

To obtain an in-depth explanation about teachers' functional competency, the researchers explore further about the relationship strength between teachers' functional competency variables and its two dimensions. Finding showed that teachers' functional competency has very strong positive relationship and significant with both the dimensions. However, the correlation between the level of teachers' functional competency with teachers' level of knowledge $(r=.96, p=.00)$ is less strong compared to the strong relationship between teachers' functional competency and teachers' skill level $(r=.99, p=.00)$ as shown in Table 5 .

Table 5

Correlation between Teachers' Functional Competency, Teachers' Knowledge and Teachers' Skills $(\mathrm{N}=225)$

\begin{tabular}{lcll}
\hline & $\begin{array}{l}\text { Teachers' Functional } \\
\text { Competency }\end{array}$ & $\begin{array}{l}\text { Teachers' } \\
\text { Knowledge }\end{array}$ & $\begin{array}{l}\text { Teachers' } \\
\text { Skills }\end{array}$ \\
\hline Teachers' Functional & - & $.96^{* * *}$ & $.96^{* * *}$ \\
Competency & $.96^{* *}$ & - & $.83^{* *}$ \\
Teachers' Knowledge & $.99^{* *}$ & $.83^{* *}$ & - \\
Teachers' Skills & 225 & 225 & 225 \\
$\mathrm{~N}$ &
\end{tabular}

$\mathrm{N}$ **. Correlation is significant at confidence level 0.01

As a conclusion, researchers summarize all the findings in Diagram 2 below so that readers are able to see clearly the correlation that exists for both variables followed by correlation with its dimensions. 


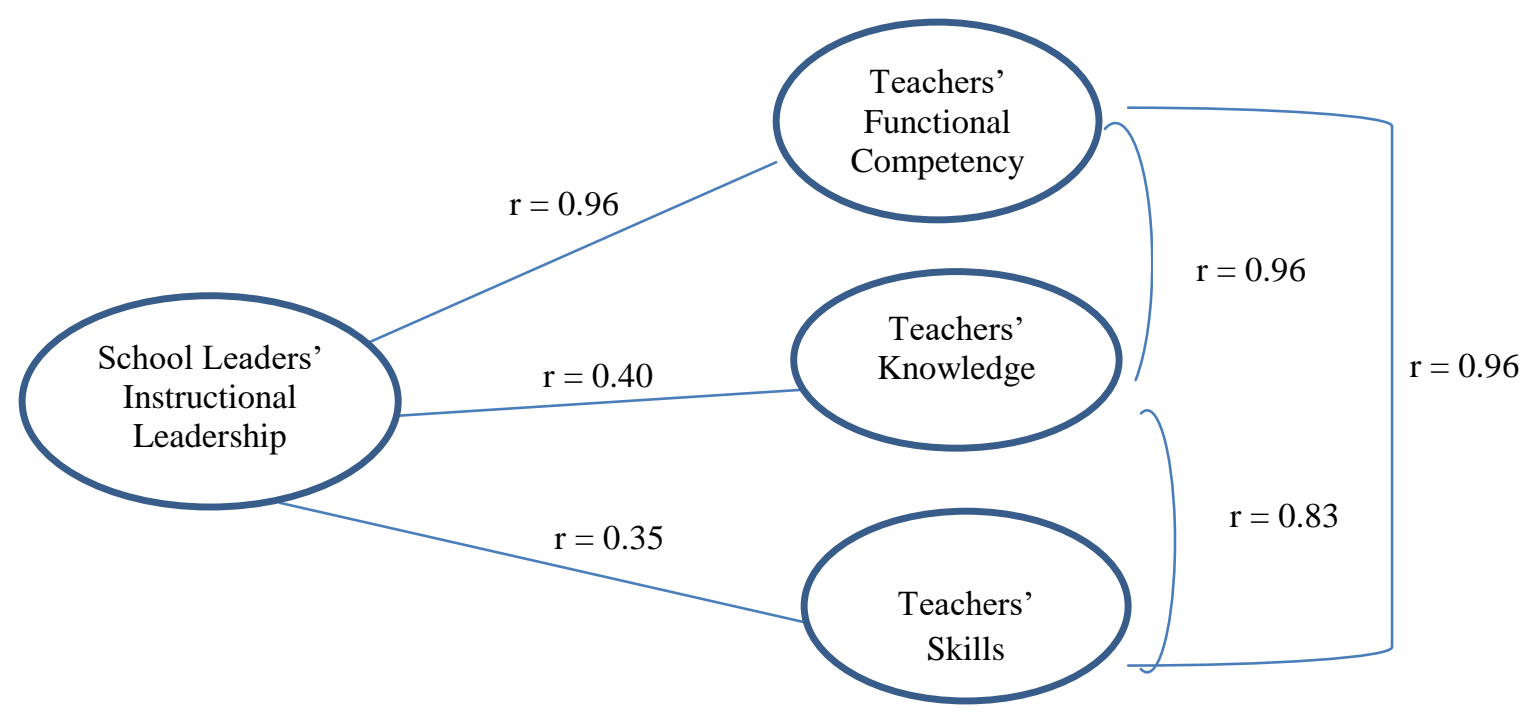

Diagram 2

Correlation between instructional leadership and teachers' functional competency and its dimensions

\section{CONCLUSION}

In conclusion, study findings showed there is strong positive correlation between the two variables. School leaders' instructional leadership has strong positive relationship and significant towards teachers' functional competency. However, in terms of dimensions for teachers' functional competency, findings showed school leaders' instructional leadership has a strong relationship with teachers' knowledge but a weak relationship with teachers' skills. This shows that school leaders' instructional leadership impacts teachers' functional competency, especially in teachers' knowledge dimension. For the aspect of teachers' functional competency, teachers' skills dimension showed strong correlation compared to teachers' knowledge. This shows that teachers' skills are very important and are much more needed for a teacher to have a high functional competency. However, to obtain the skills, teachers have to have a wide and in depth knowledge in all aspects of their quality teaching development.

To achieve these desired outcomes, instructional leadership theory (Hallinger \& Murphy, 1985) need to be embedded with social learning theory (Bandura, 1986) because it is significantly inspired by the elements behaviourist and cognitive learning theories, which encompasses attention, memory, and motivation. According to Bandura (1986), the world and a person's behaviour cause each other, while behaviourism essentially states that one's environment causes one's behaviour. Later, Bandura soon considered personality as an interaction between three components: the environment, 
behaviour, and one's psychological processes (one's ability to entertain images in minds and language). The terms environment in this study refer to the environment of the school and it means that promoting school learning climate which is identified as one of the three dimensions in the instructional leadership framework (Hallinger \& Murphy, $1985)$ is very important to inspire the teachers' functional competency.

This clearly shows that school leaders' instructional leadership practice is able to increase the level of teachers' functional competency (Ross, Hogaboam-Gray, \& Gray, 2004; Ebmeier, 2003) and also success in teachers' classroom instructions; and at the same time the increase in students' academic achievement can be realized (Hendriks \& Steen, 2012; Moolenaar, Sleegers, \& Daly, 2012; Fancera \& Bliss 2011; Guo, Piasta, Justice, \& Kaderavek, 2010; Caprara, Barbaranelli, Steca, \& Malone, 2006; Hallinger \& Heck, 1998).

As an additional suggestions, school leaders should practice instructional leadership style which is believed to be strong and significant and have positive relationship with teachers' functional competency. Therefore, it is hoped that this study finding can be a guideline to the stakeholders involved with education leadership in making strategies and quality improvements in education, specifically in leadership aspect in schools. School leaders should be exposed to the concept, theory and instructional leadership practice in completing their tasks and responsibilities because this will help increase teachers' functional competency and success in classroom instructions can be materialized.

It is proven in this study that teachers' with high level of functional competency will be able to use the in-depth knowledge of their content subjects and with the high level of functional skills teachers are able to ensure that the objectives of their classroom teaching and learning are achieved successfully. A competent teacher will give high commitment and are sensitive towards the students' learning needs and problems faced by their students, are able to make fair assessment, give clinical guidance, ensure that students understand what they are being taught and also nurture students' interest and persistence to attain success.

In short, instructional leaders should make changes by ensuring that teachers teach and students learn, guaranteeing that classrooms are equipped with various facilities for the enhancement of teaching and learning processes, securing that the teaching and learning time is abided by all teachers, planning school aims and warranting that they are understood and complied by all teachers and students (Hallinger, 2005). School administrators have the duty to plan curriculum programs, supervise and evaluate classroom instructions, implement remedial or corrective actions on problematic aspects, ensure that teaching and learning time is not disturbed and that teachers have the audacity to teach efficiently by organizing staff development programs; and monitor students' behaviours. In line with the $21^{\text {st }}$ century learning, school administrators should make certain that classroom instructions are done by realizing the concept of inculcating High Order Thinking Skills (HOTS) and student-centred teaching and learning through the use of technology and effective audio visual aids (Yu, Luo, Sun, \& Strobel, 2012). 


\section{REFERENCES}

Anderson, L.W. (1991). Increasing Teacher Effectiveness, UNESCO: International Institute For Educational Planning, Paris.

Ary, D., Jacobs, L. C., \& Razavieh, A. (2002). Introduction to research in education. Sixth Edition. USA : Wadsworth Group.

Ball, D.L. \& Mc Diarmid, G.L. (1990). The subject matter preparation of teachers. In W.R. Housten, (ed). Handbook of Research in Teacher Education, 38, 2-8

Bandura, A. (1986). Social foundations of thought and action. Englewood Cliffs, NJ: Prentice-Hall.

Blanchard, P. N., \& Thacker, J. W. (2004). Effective training: Systems, strategies, and practices (2nd Ed.). Upper Saddle River, NJ: Person Education, Inc.

Blasé, J., \& Blasé, J. (2000). Effective instructional leadership: Teachers ${ }^{\text {ee }}$ perspectives on how principals promote teaching and learning in schools. Journal of Educational Administration, 38(2), 130-141

Brophy, J. (1992). Probing the subtleties of subject-matter teaching. Educational Leadership, 49 (7), 4-8.

Buczynski, S. \& Hansen, C. B. (2010). Impact of professional development on teacher practice: Uncovering connections. Teaching and Teacher Education, 26, 599-607.

Caprara, G. V., Barbaranelli, C., Steca, P., \& Malone, P.S. ( $\beta 006)$. Teachers' selfefficacy beliefs as determinants of job satisfaction and students' academic achievement: A study at the school level. Journal of School Psychology, 44(6), 473-490.

Cooley, V.E., \& Shen, J. (2010). School accountability and professional job responsibilities : A perspective from secondary principals. NASSP Bulletin, 87 (634), $10-25$.

Council on Education for Public Health. (2006). Competencies and learning objectives. Retrieved Feb. 12, 2012 from http://www.ceph.org/pdf/Competencies_TA.pdf.

Darling-Hammond, I. (1999). Teacher quality and student achievement: a review of state policy evidence. Education policy analysis archives, 8(1), 1-40.

Ebel, R. (1951). Estimation of the reliability of ratings. Psychometrika, 16, 407-424.

Ebmeier, H. (2003). How supervision influences teacher efficacy and commitment: An investigation of a path model. Journal of Curriculum and Supervision, 18(2), 110-141

Eileen Lai Horng, Daniel Klasik, \& Susanna Loeb. (2010). Principal's time use and school effectiveness. American Journal of Education, 116(4), 491-523.

Fancera, S. F., \& Bliss, J. R. (2011). Instructional leadership influence on collective teacher efficacy to improve school achievement. Leadership and Policy in Schools, 10(3), 349-370. 
Goldring, E., Huff, J., May, H., \& Camburn, E. (2008). School context and individual characteristics: What influences principal practice? Journal of Educational Administration, 46(3), 332-352.

Grossman, P. (1990). The making of a teacher. New York: Teachers College Press.

Gu Saw Lu. (2014). The Relationships Between Instructional Leadership Behavior, School Climate and Teacher Efficacy in Secondry Schools in Kedah. Thesis Doctor of Philosophy, Northern University of Malaysia.

Guo, Y., Piasta, S. B., Justice, L. M., \& Kaderavek, J. N. (2010). Relations among preschool teachers' self-efficacy, classroom quality, and children's language and literacy gains. Teaching and Teacher Education, 26(4), 1094-1103.

Hallinger, P. (2010). Making education reform happen: Is there an 'Asian' way? School Leadership and Management, 30 (5),401-419.

Hallinger, P. (2005). Instructional leadership and the school principal: A passing fancy that refuses to fade away. Leadership and Policy in Schools, 4(3), 221-239.

Hallinger, P., \& Heck, R. H. (1998). Exploring the principal's contribution to school effectiveness: 1980-1995. School Effectiveness and School Improvement, 9 (2), 157191.

Hallinger, P., \& Murphy, J. (1985). Assessing the instructional management behaviors of principals. The Elementary School Journal, 86(2), 217-247.

HayGroup Malaysia. (2003). Research findings on Malaysian civil service competency model. Kuala Lumpur.

Hendriks, M., \& Steen, R. (2012). Results from school leadership effectiveness studies (2005-2010). In J. Scheerens (Ed.), School leadership effects revisited: Review and meta-analysis of empirical studies (pp. 65-129). New York: Springer.

Hoy, W. K., \& Tarter, C. J. (2011). Positive psychology and educational administration: An optimistic research agenda. Educational Administration Quarterly, 47(3), 427-445.

Huber, S. G., \& Muijs, D. (2010). School leadership effectiveness: The growing insight in the importance of school leadership for the quality and development of schools and their pupils. In S. G. Huber (Ed.), School leadership-International perspectives (pp. $57-$ 77). New York: Springer.

James P. Spillane, Eric M. Camburn, Amber Stitziel Pareja. (2007). Taking a Distributed Perspective to the School Principal's Workday. Leadership and Policy in Schools, 6(1), 103-125

Kim, R. Y., Ham, S.-H., \& Paine, L. W. (2011). Knowledge Expectations in Mathematics Teacher Preparation Programs in South Korea and the United States: Towards International Dialogue. Journal of Teacher Education, 62(1), 48-61. 
Klassen, R. M., \& Chiu, M. M. (2010). Effects on teachers' self-efficacy and job satisfaction: Teacher gender, years of experience, and job stress. Journal of Educational Psychology, 102(3), 741-756.

Lahui-Ako, B. (2001). The instructional leadership behavior of Papua New Guinea high school principals: A provincial case study. Journal of Educational Administration, 39(3), 233-265

Leithwood, K., Day, C., Sammons, P., Hopkins, D. \& Harris, A. (2006), Successful School Leadership: What It Is and How It Influences Pupil Learning. London: Department for Education and Skills.

Leithwood, K., \& Jantzi, D. (2006). Transformational school leadership for large-scale reform: Effects on students, teachers, and their classroom practices. School Effectiveness and School Improvement, 17(2), 201-227.

Leithwood, K. (2001). School leadership and educational accountability, International Journal of Educational Leadership, 3(4), 217-237.

Main, S., \& Hammond, L. (2008). Best practice or most practiced? Pre-service teachers' beliefs about effective behavior management strategies and reported self-efficacy. Australian Journal of Teacher Education, 33(4), 28-38

Malaysian Education Ministry. (2014). Integrated Assessment Module for Education Services Officers (PBPPP), Curriculum Development Division, Ministry of Education Malaysia.

Malaysia Public Service Department. (2004).

McClelland, D. (1973). Testing for competence rather than intelligence. American Psychologist, 28, 1-14.

McCoy, R. (2001). Computer competencies for the 21st century information systems educator. Information Technology, Learning, and Performance Journal, 19(2). 21-35.

Moolenaar, N. M., Sleegers, P. J. C., \& Daly, A. J. (2012). Teaming up: Linking collaboration networks, collective efficacy, and student achievement. Teaching and Teacher Education, 28(2), 251-262.

Murphy, J., Elliott, S. N., Goldring, E., \& Porter, A. C. (2007). Leadership for learning: A research-based model and taxonomy of behaviors. School Leadership and Management, 27(2), 179-201.

National Council of Teachers of Mathematics (NCTM). (2000). Principles and standards for school mathematics. Reston, VA.

Nijveldt, M., Beijaard, D., Brekelmans, M., Verloop, N., \& Wubbels, T. (2005). Assessing the interpersonal competence of beginning teachers: the quality of the judgment process. International Journal of Educational Research, 43, 89-102. 
Northouse, P. G. (2004). Leadership: Theory and Practice. (3rd ed.). California: Sage Publications.

Ornstein, A.C. (1991). Teacher effectiveness research: theoritical consideration, in Waxman, H.C. and Walberg, H.J. Effective Teaching: Current Research, McCutchan Publishing Corp. Berkeley.

Quinn, D. M. (2002). The impact of principal leadership behaviors on instructional practice and student engagement. Journal of Educational Administration, 40(5), 447467.

Rice, J. K. (2003). Teacher quality: Understanding the effectiveness of teacher attributes. Washington, D.C.: Economic Policy Institute.

Rowan, B. (2004). Teachers matter: evidence from value-added assessments. AERA Research Points: Essential Information for Educational Policy, 2(2), 1-4.

Robinson, V. M. J., Lloyd, C. A., \& Rowe, K. J. (2008). The impact of leadership on student outcomes: An analysis of the differential effects of leadership types. Educational Administration Quarterly, 44(5), 635-674.

Rosnarizah Abdul Halim. (2015). Distributed leadership, contextual factor and teacher self-eficacy in Malaysia. Educational Leadership Journal, 2(4).

Ross, J. A., Hogaboam-Gray, A., \& Gray, P. (2004). Prior student achievement, collaborative school processes, and collective teacher efficacy. Leadership and Policy in Schools, 3(3), 163-188.

Safia Saeed. (2009) . Evaluation Study Of Competencies Of Secondary School Teachers In Punjab In The Context Of Classroom Management, University of Wah, Pakistan. Journal of College Teaching \& Learning, November 2009.

Sekaran, U. (2003). Research methods for business: A Skill Building Approach (3rd. ed.), New York. John Wiley \& Sons, Inc.

Shen, J., Cooley, V. E., Reeves, P., Burt, W. L., Ryan. L., Rainey, J. M., \& Yuan, W. (2010). Using data for decision-making: Perspectives from 16 principals in Michigan, USA. International Review of Education, 56(4), 435-456

Spillane, J. P., Camburn, E. M., \& Pareja, A. S. (2007). Taking a distributed perspective to the school principal's workday. Leadership and Policy in Schools, 6(1), 103-125.

Stangor, C.O. (2004). Research Methods For Behavioural Sciences. Boston: Houghton Mifflin Co.

Wayne, A. M., \& Youngs, P. (2003). Teacher characteristics and student achievement gains: A review. Review of Educational Research, 73(1), 89-122.

Whitehurst, G.J. (2002). Improving teacher quality, Spectrum Lexicon, 75, 12-16 
Witziers, B., Bosker, R. J., \& Kruger, M. L. (2003). Educational leadership and student achievement: The elusive search for an association. Educational Administration Quarterly, 39(3), 398-425

Yu, J. H., Luo, Y., Sun, Y., \& Strobel, J. (2012). A Conceptual K-6 Teacher Competency Model for Teaching Engineering. Procedia - Social and Behavioral Sciences, 56(Ictlhe), 243-252. 